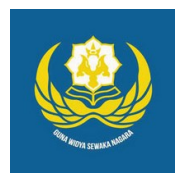

Jurnal Analogi Hukum

Journal Homepage: https://ejournal.warmadewa.ac.id/index.php/analogihukum

\title{
Perlindungan Hukum Terhadap Saksi Pelaku Yang Bekerjasama (Justice Collaborator) dalam Perkara Tindak Pidana Korupsi
}

\author{
Antonius Yoseph Bou*, I Nyoman Sujana dan I Ketut Sukadana \\ Universitas Warmadewa, Denpasar-Bali, Indonesia \\ *yosephbou@gmail.com
}

How To Cite:

Bou, A, Y., Sujana, I, N., Sukadana, I, K. (2020). Perlindungan Hukum Terhadap Saksi Pelaku Yang Bekerjasama (Justice Collaborator) dalam Perkara Tindak Pidana Korupsi. Jurnal Analogi Hukum. 2 (2). 142-147. Doi: https://doi.org/10.22225/ah.2.2.1886.142-147

\begin{abstract}
Corruption is a particular type of crime that is serious because corruption can cause economic losses to a country that threatens the continuity of development in all aspects of a country, so that an extraordinary handling is needed. The involvement of a witness as well as a perpetrator is a breakthrough that can help law enforcement officials in uncovering the complexity of criminal acts of corruption. The choice to act as a witness as well as a perpetrator who assists or cooperates with law enforcement officials is a full risk choice for that it is realized the need for a concept of protection for a witness as well as a collaborating actor so that those who are called witnesses as well as these actors can provide information needed freely without fear of threats or intimidation by parties who are directly harmed by the testimony given. Based on the description above, the issues raised will be the subject of further discussion which are deemed necessary for a learning space around the perpetrators acting as witnesses. As for those problems, namely: how is the legal arrangement for a witness who is also an actor who helps law enforcement officials in uncovering a corruption case and how the government guarantees to provide protection for witnesses and also as perpetrators in corruption cases. To answer this problem, normative research methods are used, namely by implementing a legislative approach that examines the applicable laws and regulations and adopting a conceptual approach, namely reviewing library materials in the form of theories and opinions of legal experts. Legal arrangements for a witness as well as perpetrators are regulated in a number of laws and regulations that provide the basis of guidelines for witnesses and also those who work together in disclosing corruption cases, while we can find these regulations in witness and victim protection laws. Where it provides a guarantee of legal certainty which is characteristic of the law itself because without legal certainty it is impossible to achieve legal ideals, namely the existence of justice.
\end{abstract}

Key words: Corruption, collaborating witnesses, legal protection

\begin{abstract}
Abstrak-Korupsi merupakan salah satu jenis kejahatan tertentu yang bersifat serius di karenakan korupsi dapat menyebabkan kerugian ekonomi sebuah Negara yang mengancam kelangsungan pembangunan dalam segala aspek sebuah Negara, sehingga jelas dibutuhkan sebuah penanganan yang bersifat luar biasa. Keterlibatan seorang saksi sekaligus sebagai pelaku merupakan sebuah terobosan yang dapat membantu aparat penegak hukum dalam mengungkap rumitnya tindak pidana korupsi. Pilihan untuk bertindak sebagai seorang saksi sekaligus sebagai pelaku yang membantu atau bekerja sama dengan aparat penegak hukum merupakan sebuah pilihan penuh risiko untuk itu memang disadari perlunya sebuah konsep perlindungan bagi seorang saksi sekaligus sebagai pelaku yang bekerjasama sehingga mereka yang disebut sebagai saksi sekaligus sebagai pelaku ini dapat memberikan keterangan yang dibutuhkan secara bebas tanpa rasa takut dari ancaman atau intimidasi pihak-pihak yang secara langsung dirugikan oleh karena kesaksian yang diberikan tersebut. Berdasarkan uraian diatas diangkat permasalahan yang akan menjadi pokok bahasan selanjutnya yang dianggap perlu untuk sebuah ruang pembelajaran seputar pelaku yang bertindak sebagai saksi, adapun permasalahan tersebut yaitu: bagaimana pengaturan hukum bagi seorang saksi yang juga sebagai pelaku yang membantu aparat penegak hukum dalam mengungkap sebuah perkara korupsi dan bagaimana jaminan pemerintah untuk memberikan perlindungan bagi saksi dan juga sebagai pelaku dalam perkara korupsi. Untuk menjawab permasalahan ini digunakan metode penelitian normatif yaitu dengan melakukan pendekatan perundang-undangan yang mengkaji peraturan perundang - undangan yang berlaku dan melakukan
\end{abstract}

Jurnal Analogi Hukum, Volume 2, Nomor 2, 2020. CC-BY-SA 4.0 License 
pendekatan konseptual yaitu mengkaji bahan - bahan kepustakaan dalam bentuk teori - teori dan pendapat para pakar hukum. Pengaturan hukum bagi seorang saksi sekaligus sebagai pelaku diatur dalam beberapa peraturan perundang - undangan yang memberikan dasar - dasar pedoman seputaran saksi dan juga pelaku yang bekerja sama dalam pengungkapan kasus korupsi, adapun peraturan - peraturan tersebut dapat kita temukan dalam undang - undang perlindungan saksi dan korban dimana memberikan sebuah jaminan adanya kepastian hukum yang merupakan ciri dari hukum itu sendiri dikarenakan tanpa kepastian hukum tidak mungkin dicapainya cita hukum yaitu adanya keadilan.

\section{Kata kunci: Korupsi, saksi pelaku yang bekerja sama, perlindungan hukum}

\section{Pendahuluan}

Kejahatan korupsi merupakan salah satu jenis kejahatan tertentu dalam ilmu Hukum Pidana yang sangat serius selain tindak pidana narkotika dan kejahatan yang sifatnya terorganisir lainnya. Pemerintah Indonesia memerangi korupsi dengan menerapkan Undang-Undang Antikorupsi, di samping membangun Komisi Pemberantasan Tindak Pidana Korupsi (KPK) untuk menegakkan pelaksanaan program pemberantasan korupsi (Soemanto, Sudarto, \& Sudarsana, 2014). Kejahatan ini merupakan suatu tindak pidana yang disebut sebagai kejahatan luar biasa dikarenakan akibat dari kejahatan ini yang sangat mengancam kelangsungan perekonomian suatu Negara yang berimbas terhadap pembangunan dalam segala aspek bernegara dan sempat ditulis oleh sebuah jurnal luar negeri yang mengatakan korupsi adalah merupakan pandangan dan jalan kehidupan di Indonesia (Danil, 2014). Sehingga jelas dibutuhkan extraordinary measure/ extraordinary enforcement (penanganan yang luar biasa) dalam rangka pencegahan dan pemberantasan apa saja yang terkait didalamnya (Chazawi, 2008). Proses pemberantasan korupsi merupakan suatu yang rumit bagi siapa pun yang terlibat didalamnya khususnya aparat penegak hukum, Oleh karena itu pemberantasan korupsi merupakan salah satu fokus utama Pemerintah dan Bangsa Indonesia (Waluyo, 2014). Kesulitannya terletak dalam hal membuktikan kejahatan korupsi dipengadilan melalui pembuktian dari kedua belah pihak hakim dapat sampai pada sebuah kesimpulan dimana nilai keadilan yang hendak dicapai dalam proses peradilan. Penegakan dan pengungkapan mega skandal korupsi akan semakin sulit jika melibatkan mereka yang mempunyai power dalam sistem birokrasi negara yang terkadang memunculkan risiko bagi mereka yang ada didalamnya. Profesionalisme dan perlindungan para penegak hukum dan mereka yang terlibat dalam proses pengungkapan tindak pidana tersebut semakin di tingkatkan aturan-aturan secara dinamis diperbaharui dan diperketat dengan tujuan semakin mempermudah jalan untuk mengungkap dan menemukan aktor utama dan oknum dari tindak pidana korupsi. Salah satu terobosan Hukum dalam usaha mengatasi semua permasalah seputaran korupsi adalah dengan diterbitkannya Surat Edaran Mahkamah Agung (SEMA) Nomor 04 tahun 2011 tentang "Perlakuan bagi Pelapor Tindak Pidana (Whistle blower) dan Saksi Pelaku yang Bekerja sama (justice collaborator) dalam perkara tindak pidana tertentu" disisi lain peran sebagai justice Collaborator bukanlah suatu perkara mudah, dengan bertindak sebagai saksi sekaligus sebagai pelaku yang memberikan kesaksian seputar korupsi dimana dia sendiri juga terlibat didalamnya yang notabene mengetahui semua hal, siapa saja yang terlibat, siapa pelaku utamanya hal tersebut berimbas secara langsung pada kesaksian yang dapat memberatkan pelaku - pelaku kejahatan yang lainnya dalam proses peradilan sehingga sudah tentu akan ada upaya untuk menggagalkan atau membungkam kesaksian dari saksi sekaligus pelaku tersebut. Di Indonesia pemenuhan terhadap hak - hak saksi berupa hak untuk mendapatkan perlindungan dapat kita temukan dalam peraturan perundang - undangan khususnya undang-undang yang mengatur seputar tentang saksi dalam proses peradilan pidana yang terkait dengan korupsi ataupun tindak pidana lainnya yang sifatnya terorganisir. Adanya undang - undang tersebut sekilas memberikan jaminan perlindungan dengan adanya kepastian hukum sehingga semakin merangsang partisipasi publik untuk ikut serta dalam proses pengungkapan tindak pidana korupsi.

Bagaimana pengaturan hukum terhadap saksi pelaku yang bekerjasama dalam perkara tindak pidana korupsi, Bagaimana bentuk perlindungan hukum terhadap saksi pelaku yang bekerjasama yang memberikan keterangan di depan sidang pengadilan dalam perkara tindak pidana korupsi; dari:

Adapun tujuan dari penelitian yang terdiri

\section{Metode}

Tipe penelitian ini merupakan tipe penelitian normatif, dengan tujuan untuk mendapatkan perundang-undangan yang 
selanjutnya dikaji terkait dengan permasalan yang menjadi pokok bahasan dalam penelitiaan tersebut. Sedangkan pendekatan masalahnya menggunakan metode pendekatan perundangundangan dan pendekatan konseptual. Pendekatan perundang-undangan maksudnya pendekatan yang dilakukan berdasarkan ketentuan hukum atau norma yang berlaku. Sedangkan pendekatan konseptual adalah mengacu pada asas-asas konsep seputar masalah yang menjadi pembahasan.

Sumber Bahan hukum yaitu bahan hukum yang mengikat meliputi peraturanperaturan pokok dalam hukum pidana yang menjadi landasan bagi keberadaan seorang saksi dan juga sebagai pelaku yang lahir untuk menjamin adanya kepastian hukum, salah satunya yang menjadi sumber dakam penelitian tersebut adalah UU perlindungan bagi saksi dan korban;

Bahan hukum sekunder yang dikaji adalah teori-teori hukum dan pendapat para serjana yang berkaitan dengan pokok masalah yang dibahas;

Bahan hukum tersier meliputi kamus hukum dan ensiklopedia sebagai penunjang pembahasan tulisan.

\section{Hasil Penelitian Dan Pembahasan}

\section{Pengaturan Hukum Terhadap Saksi Pelaku yang Bekerjasama dalam Perkara Tindak Pidana Korupsi}

Dalam proses pengungkapan kasus pidana terutama yang terkait dengan korupsi adanya alat bukti merupakan suatu hal yang penting dikarenakan dengan mengacu pada alat - alat bukti tersebut hakim dapat memutuskan perkara berdasarkan apa yang diyakininya. Alat - alat bukti yang memiliki peranan penting dalam pengungkapan kasus korupsi menurut peraturan perundang - undangan ada lima alat bukti, keterangan dari seorang saksi merupakan satu dari lima alat bukti tersebut. Keterangan dari saksi memiliki nilai pembuktian yang besar yang dapat membantu seorang tersangka bebas dari tuntutan jaksa atau sebaliknya semakin memberatkan tersangka tersebut. Sebagimana dimaksud dalam definisinya yang terkait didalam proses peradilan pidana dalam arti khusus saksi merupakan orang - orang yang berada atau terlibat dalam proses terjadinya tindak pidana. Pendefinisian tentang saksi dan saksi yang juga sebagai pelaku diberikan dengan cara berbeda - beda tetapi pada dasarnya mempunyai substansi yang sama sebagai orang yang membantu proses penyidikan, penuntutan dan peradilan entah itu sebagai seorang saksi yang kesaksiannya dapat membantu tersangka lolos dari jerat hukum ataupun sebagai seorang saksi yang kesaksiannya semakin memberatkan tersangka untuk bebas dari tuntutan jaksa. Terkait dengan defenisi saksi diatas patut diketahui juga bahwa berdasarkan putusan Mahkamah Konstitusi telah memberikan makna tambahan bahwa keterangan yang diberikan saksi juga tidak sebatas yang ia lihat sendiri, ia dengar sendiri dan ia alami sendiri, hal ini berimbas pada adanya saksi yang hanya mendengar dari keterangan orang lain saja. adalah:

Sedangkan defenisi keterangan saksi

Salah satu alat bukti dalam perkara pidana yang berupa keterangan dari saksi mengenai suatu peristiwa pidana yang ia dengar sendiri, ia lihat sendiri dan ia alami sendiri dengan menyebut alasan dari pengetahuannya itu.

Pada perkembangan terakhir diindonesia bertolak dari penting adanya seorang saksi sekaligus sebagai pelaku yang diharapkan dapat membantu pengungkapan korupsi oleh penegak hukum dan juga sebagai tuntutan adanya kepastian hukum bagi mereka yang bertindak sebagai saksi dan juga pelaku maka MA berdasarkan wewenangnya mengeluarkan surat edaran yang bertujuan untuk menyamakan pandangan lembaga - lembaga yang terkait dalam proses peradilan pidana khususnya terkait dengan korupsi. Hal ini penting adanya mengingat minimnya pengaturan sehubung dengan keberadaan seorang saksi dan juga sebagai pelaku yang merupakan fenomena baru dalam dunia Hukum, langkah MA tersebut telah memberikan jawaban akan adanya kekosongan Hukum dan informasi terkait saksi dan juga sebagai pelaku padahal keberadaannya dipandang sangat penting karena kesaksiannya merupakan kesaksian dari seorang pelaku yang juga sama - sama terlibat dalam kejahatan yang awalnya sangat tertutup dan rumit pengungkapannya oleh penegak Hukum. Dalam surat edaran tersebut juga telah memberikan dengan jelas dan tegas batasan - batasan dalam menentukan siapa saja yang bisa disebut sebagai saksi yang diambil dari pelaku - pelaku kejahatan sehingga tidak dengan mudah seorang mengajukan atau mengklaim status sebagai saksi pelaku hanya dikarenakan adanya berbagai perlindungan dan penghargaan yang ditawarkan apabila status saksi dan juga sebagai pelaku yang mau bekerja sama dengan aparat penegak Hukum membongkar tindak pidana 
korupsi tersebut. Jika dihubungkan dengan fakta yang terjadi di Indonesia akhir - akhir ini dimana banyak dijumpai atau didengar bahwa terjadi banyak penolakan dari lembaga lembaga terkait pengajuan diri beberapa pelaku untuk sekaligus menjadi saksi yang mana hal ini jelas diatur dalam surat edaran MA tersebut sehubung dengan kriteria - kriteria menjadi saksi dan juga pelaku yang bekerja sama.

Jadi kehadiran saksi pelaku disini diposisikan sebagai informan atau orang dalam sesuai dengan pedoman menjadi saksi sekaligus pelaku dimana dia sendiri juga terlibat didalamnya. Begitu pentingnya peran seorang saksi yang juga sebagai pelaku dari kejahatan tersebut dalam membongkar kejahatan korupsi tanpa keterlibatan saksi tersebut pasti penyidik akan menemukan kendala dalam pengungkapan kasus korupsi tersebut, hal ini seperti apa yang dikemukakan oleh Abdul Haris Semendawi bahwa pada konsep pengungkapan keberadaan seorang saksi pelaku yang bekerjasama menjadi hal yang sangat penting dalam rangka membongkar jaringan kejahatan yang selama ini tertutup rapi dan sangat terorganisir (Semendawi, 2014). Kehadiran saksi pelaku yang bekerjasama merupakan salah satu terobosan hukum dalam upaya membongkar suatu kejahatan yang terorganisir seperti jaringan mafia termasuk korupsi yang biasa dilakukan secara berjamaah yang pada awalnya tidak bisa diungkap karena kurangnya alat-alat bukti dan juga keterangan dari saksi.

Pengaturan hukum merupakan sebuah landasan untuk menjamin adanya kepastian Hukum karena tanpa adanya kepastian Hukum maka tidak mungkin tercainya cita - cita hukum yaitu keadilan. Dengan pengaturan tersebut bagi seorang saksi dan juga sebagai pelaku memberikan koridor bagi eksistensi atau keberadaannya dalam proses peradilan pidana. Ide saksi pelaku yang bekerja sama di Indonesia sebenarnya bertitik tolak dari ketentuan UNCAC dimana merupakan konvensi internasional yang meletakkan dan menyepakati dasar - dasar hukum sehubung dengan kejahatan korupsi dan bagaiman cara pengungkapannya. Indonesia sebagai satu Negara yang terlibat didalamnya sebagai bentuk pertisipasi dalam hubungan internasional jelas menjadikan hasil konvensi ini sebagai pedoman dalam mengatur perundang - undangan nasional terkait dengan korupsi. Bertolak dari kesadaran akan pentingnya melibatkan seorang saksi dan juga sebagai pelaku dalam proses pengungkapan kasus - kasus yang sangat sulit dalam mengetahui siap sesungguhnya pelaku utamanya dan bagaimana sistem korupsi yang dijalankan, maka perlu pengaturan yang lebih komprehensif dalam meletakkan dasar - dasar dan batasan - batasan keberadaan atau eksistensi saksi dan juga sebagai pelaku dalam membantu mengungkap tabir gelap kasus kasus mega skandal korupsi yang tekadang juga melibatkan aparat penegak hukum atau mereka yang juga memiliki power yang bisa mengintervensi proses peradilan. Berbagai pengaturan Hukum telah lahir dan selalu diperbaharui untuk selalu disesuaikan dengan perkembangan tuntutan hukum masyarakat yang bergerak dinamis yang selalu dilandasi dengan semangat pemberantasan korupsi yang dewasanya ini semakin dihadapkan dengan tantangan - tantangan yang juga semakin berat. .

\section{Bentuk Perlindungan Hukum Terhadap Saksi Pelaku yang Bekerjasama yang Memberikan Keterangan Di Depan Sidang Pengadilan dalam Perkara Tindak Pidana Korupsi}

Perlindungan hukum merupakan segala bentuk perlindungan untuk menjamin hak - hak seseorang sebagai warga Negara dalam hubungan dengan masyarakat dimana ada jaminan dari Negara yang dimplementasikan lewat adanya peraturan Hukum atau suatu hal yang memberikan perlindungi kepada subyek hukum melalui undang-undang yang berlaku dengan sanksi yang tegas (Muchsin, 2003). Negara lewat peraturan hukum telah memberikan koridor dalam kehidupan berbangsa dan bernegara sehingga hak - hak orang lain tidak bisa dirugikan secara sewenang - wenang. Perlindungan merupakan kewajiban dari Negara sebagaimana termaktub dalam UUD Negara Republik Indonesia. Perlindungan terhadap masyarakat yang menjadi saksi dan juga sebagai pelaku merupakan sebuah langkah yang patut di apresiasi dikarenakan sifat pentingnya keterangan dari saksi tersebut dalam membantu penegak hukum menyelesaikan sebuah perkara Korupsi yang sulit pengungkapannya jikalau tanpa melibatkan mereka yang benar - benar mengetahui seluk beluk sistem korupsi yang dijalankan dalam kasus tersebut.

Tanpa adanya optimalisasi perlindungan hukum bagi mereka yang dikatagorikan sebagai saksi dan juga sebagai pelaku tersebut maka upaya penegakan hukum akan mengalami kesulitan besar dalam pengungkapan tindak pidana korupsi. Pada umumnya akan ditemukan kendala - kendala dalam pengungkapan kasus korupsi yang terorganisir diantaranya :

Kejahatan korupsi tersebut dilakukan dengan rapi, profesional dengan modus 
operandi yang super canggih ;

Mereka yang terlibat dalam kasus korupsi yang dilakukan secara berjamaah tersebut tidak mungkin saling melaporkan;

Korupsi dewasa ini sering melibatkan mereka yang memiliki power atau kekuatan (kekuasaan, jabatan, finansial) sering disebut sebagai kejahatan kerah putih sehingga orang takut untuk memberikan kesaksian;

Modus korupsi yang bisa dibilang canggih yang selalu di sesuaikan dengan bagaimana cara pencegahan dan pengungkapannya oleh penegak hukum sehingga ada anggapan yang menyatakan bahwa kejahatan juga selalu berubah dinamis sesuai dengan perubahan bagaimana pencegahannya ;

Transaksi dilalukan secara tunai lewat orang ke tiga dan jarang melakukan komunikasi lewat media untuk menghindari penyadapan;

Hasil dari korupsi sering dialihkan atas nama orang lain yang menjadi trend kebanyakan pelaku korupsi mengamankan aset - aset hasil korupsinya;

Terkadang kejahatan yang diungkap sudah lama terjadi dimana sangat sulit mengumpulkan bukti dan saksi.

Berangkat dari kesulitan - kesulitan tersebut diatas maka peran seorang saksi dan juga sebagai pelaku merupakan sebuah langkah yang patut mendapat perlindungan agar keterangan mereka bisa diberikan secara objektif tanpa rasa takut terhadap ancaman atau intimidasi dan juga perlu diapresiasi dengan pemberian penghargaan untuk menciptakan suasana yang dapat merangsang masyarakat atau pelaku kejahatan untuk bertindak sebagai seorang saksi dan juga sebagai pelaku yang bersama penegak hukum mengungkap kasus korupsi. Bertolak dari peran mereka yang luar biasa sebagia pembocor rahasia dimana mereka juga berada dan terlibat di dalam lingkaran kejahatan yang mereka ungkap maka perlu sebuah jaminan perlindungan agar dalam memberikan keterangan hal - hal yang diungkap merupakan sesuatu yang dilihat, didengar dan dialami sebagi seorang saksi dan sebagai pelaku.

Risiko - risiko yang sering dihadapi oleh seorang saksi dan juga sebagai pelaku pada umumnya datang berupa ancaman ataupun intimidasi untuk tidak bersaksi sesuai dengan keadaan yang sebenarnya dari mereka yang secara langsung ataupun tidak langsung terlibat didalam perkara korupsi tersebut, selain itu risiko seperti pemecatan, terancamnya keselamatan keluarga dan risiko hukum selalu menyertai perjalanan seorang saksi dan juga sebagai pelaku tersebut maka dari itu sistem perlindungan diperbaruhui salah satu yang paling penting adalah merahasiakan identitas saksi pelaku.

Pada umumnya terkait dengan perlindungan ada empat bentuk perlindungan bagi mereka yang di kategorikan sebagai saksi dan juga sebagai pelaku (Mulyadi, 2015):

Perlindungan tehadap fisik dan psikis ;

Penanganan khusus;

Perlindungan hukum; dan

Penghargaan.

Dengan adanya perlindungan-perlindungan diatas tersebut memberikan sebuah jaminan hukum yang sangat membantu saksi dan juga sebagai pelaku untuk secara bebas dapat memberikan kesaksian yang benar-benar objektif tanpa rasa takut dari ancaman dan sebagai bentuk apresiasi telah membantu mengungkap kasus korupsi, jaminan hukum tersebut juga memberikan penghargaan yang dapat berupa keringanan-keringanan pidana, remisi maupun pembebasan bersyarat.

\section{Simpulan}

Berdasarkan uraian-uraian dalam bab-bab terdahulu, maka dapat ditarik simpulan sebagai berikut :

Pengaturan hukum sebagai landasan untuk menjamin kepastian hukum terhadap eksistensi saksi yang juga sebagai pelaku yang berkolaborasi dengan penegak hukum dalam upaya mengungkap berbagai kasus korupsi yang rumit berawal dari ketentuan ( UNCAC) yaitu konvensi internasional Negara-Negara yang tergabung dalam Perserikatan BangsaBangsa yang bertujuan untuk bersama-sama mengatur dan menyepakati sebuah konsep peraturan demi memberantas tindak pidana korupsi yang sangat merugikan keuangan Negara yang menuntut pembangunan berkelanjutan dalam segala aspek-aspek kehidupan berbangsa dan bernegara. Kemudian berbagai produk Undang-Undang lahir dan mengalami berbagai revisi untuk menyesuaikan dengan tuntutan hukum masyarakat yang berjalan dinamis. Pengaturan-pengaturan tersebut telah memberikan koridor sebagai pedoman dalam eksistensu seorang sebagai saksi dan juga sebagai pelaku.

Bentuk-bentuk perlindungan hukum 
terhadap saksi pelaku yang bekerjasana (justice collaborator) adalah perlindungan akan hak-hak saksi pelaku sebagaimana dimaksud dalam Undang-Undang Nomor 31 Tahun 2014 tentang Perlindungan Saksi Dan Korban yang mencakup perlindungan fisik dan psikis, perlindungan hukum, penaganan khusus dan pemberian penghargaan (reward).

\section{Daftar Pustaka}

Chazawi, A. (2008). Hukum Pembuktian Tindak Pidana Korupsi. Bandung: Alumni Bandung.

Danil, E. (2014). Korupsi: Konsep, Tindak Pidana, dan Pemberantasannya. Jakarta: Rajawali Pers.

Muchsin. (2003). Perlindungan dan Kepastian Hukum bagi Investor di Indonesia. Surakarta: Univesitas Sebelas Maret Press.

Mulyadi, L. (2015). Perlindungan Hukum Whistle Blower \& Justice Collaborator Dalam Upaya Penanggulangan Organized Crime. Bandung: PT Alumni Bandung.

Semendawi, A. H. (2014). Optimalisasi Perlakuan dan Perlindungan Bagi Whistle Blower dan Justice Collaborator. In Makalah disampaikan dalam kegiatan kuliah umum Fakultas Hukum Universitas Hasanuddin. Makassar: Universitas Hasanuddin.

Soemanto, Sudarto, \& Sudarsana. (2014). PEMAHAMAN MASYARAKAT TENTANG KORUPSI. Y ustisia Jurnal Hukum, 3(1). Retrieved from https:// jurnal.uns.ac.id/yustisia/article/ view/10124

Waluyo, B. (2014). Optimalisasi Pemberantasan Korupsi Di Indonesia. JurnalYuridis, 1(2), 169-182. Retrieved from https://media.neliti.com/media/ publications/282159-optimalisasipemberantasan-korupsi-di-in6faf3218.pdf 